\title{
Analisis Pengaruh Lajur Khusus Sepeda Motor Terhadap Kinerja Simpang Jalan PH.H.Mustafa - Jalan Cimuncang
}

\author{
Bintang Anugrah Illahi dan Andrean Maulana \\ Jurusan Teknik Sipil, Fakultas Teknik Sipil dan Perencanaan, ITENAS, Bandung \\ e-mail: dezan.bintang@yahoo.com
}

\begin{abstract}
ABSTRAK
Penggunaan sepeda motor yang hampir 2 kali lipat lebih dari pengguna mobil, hal ini menyebabkan tingginya proporsi sepeda motor dalam arus lalu lintas. Diperlukan perlakuan khusus untuk mengantisipasi turunnya kinerja lalu lintas akibar para pengendara sepeda motor seperti disediakannya lajur khusus sepeda motor dan ruang henti khusus sepeda motor. Tujuan studi ini adalah menganalisis pengaruh lajur khusus sepeda motor yang menampung pergerakan sepeda motor di jalur major menggunakan model mikrosimulasi dengan software PTV Vissim. Hasil yang diperoleh dari penelitian ini menunjukan bahwa terdapat perubahan kinerja simpang yaitu panjang antrian dan tundaan lebih baik ketika menggunakan lajur khusus sepeda motor di jalur major.
\end{abstract}

Kata kunci: lajur khusus sepeda motor, mikrosimulasi, kinerja simpang bersinyal

\begin{abstract}
The use of motorbikes is almost 2 times more than car users, this causes a high proportion of motorcycles in the flow of traffic. Special treatment is needed to anticipate the decline in the traffic performance of motorbike riders such as the availability of motorbike lanes and motorbike stop rooms. The purpose of this study was to analyze the influence of the exclusive lanes of motorbikes that accommodate motorbike movements in the major lanes using the microsimulation model with the Vissim PTV software. The results obtained from this study indicate that there are changes in intersection performance, namely queue length and delay are better when using motorcycle lanes in the major lane.
\end{abstract}

Keywords: exclusive lane, mikrosimulation, signalised intersection performance 


\section{PENDAHULUAN}

Penggunaan sepeda motor yang hampir 2 kali lipat lebih dari pengguna mobil, hal seperti ini merupakan hal yang wajar bagi masyarakat di negara-negara berkembang. Mobilitas yang cukup tinggi dan harga yang relatif terjangkau menjadi salah satu alasan dipilihnya sepeda motor sebagai moda transportasi. Dari fenomena tersebut dapat dikatakan bahwa arus lalu lintas di jaringan jalan akan semakin didominasi oleh pengendara sepeda motor.

Rekayasa lalu lintas seperti disediakan lajur khusus sepeda motor menjadi isu yang sering diperbincangkan oleh masyarakat. Dengan kondisi lalu lintas yang didominasi oleh sepeda motor, perlu pengkinian metode analisis lalu lintas untuk mengantisipasi fenomena ini, salah satunya adalah metode mikroskopik. Zukhruf [1], Putri [2], Algifar [3] dan Maulana [4] adalah beberapa peneliti yang melakukan kajian lalu lintas dengan metode mikroskopik di kota-kota besar yaitu Bandung, Jogjakarta dan Makassar.

Zukhruf [1] menjelaskan bahwa penggunaan model mikrosimulasi dapat mendekati kondisi eksisting, yang ditandainya dengan perbandingan nilai kecepatan model dan hasil survey, secara berturut-turut adalah $28,61 \mathrm{~km} / \mathrm{jam}$ dan 29,39 km/jam. Dengan alat bantu ini, didapatkan hasil bahwa penggunaan lajur khusus sepeda motor di Bandung, khususnya di ruas Jalan BKR akan meningkatkan kecepatan $60 \%$. Vissim merupakan salah satu alat bantu simulasi mikroskopik atau mikrosimulasi, yang berarti mempertimbangkan setiap karakteristik kendaraan maupun pejalan kaki secara individual. Putri [2] dan Algifar [3] menggunakan alat bantu ini untuk melihat kinerja lalu lintas, yang meningkatkan akurasi hasil analisis yang dilakukan.

Penelitian ini akan menganalisis kinerja simpang di jalan P.H.H. Mustafa - Cimuncang jika dibangunnya lajur khusus sepeda motor di ruas jalan tersebut sehingga dapat dibandingkan kinerja simpang eksisting dengan kinerja simpang yang direncanakan. Alat bantu yang akan digunakan untuk simulasi mikroskopik adalah Vissim.

\section{METODOLOGI PENELITIAN}

Metode penelitian dan pengumpulan data ini dilaksanakan mengikuti diagram alir seperti pada Gambar 1. Hal pertama yang dilakukan adalah pengumpulan data, yang digunakan untuk pemodelan lalu lintas pada kondisi eksisting dan skenario. Perbandingan kinerja antara kedua kondisi tersebut menjadi simpulan dari penelitian ini.

\subsection{Pengumpulan Data Primer dan Sekunder}

Data primer yang digunakan pada penelitian ini berupa data arus lalu lintas, geometri simpang, kecepatan kendaraan dan waktu sinyal. Pengambilan data arus lalu lintas kendaraan dilakukan dengan cara merekam pergerakan kendaraan, geometri simpang dilakukan dengan cara mengukur langsung menggunakan roda pengukur, kecepatan kendaraan dengan mengolah hasil rekaman pergerakan kendaraan dari penelitian sebelumnya dan waktu sinyal dilakukan dengan cara mencatat langsung menggunakan stopwatch.

Data sekunder yang digunakan berupa parameter pergerakan kendaraan di simpang yang berasal dari penelitian sebelumnya. Data pergerakan kendaraan di simpang dilakukan pada tahun 2018 jam 16.30 18.00 WIB. 


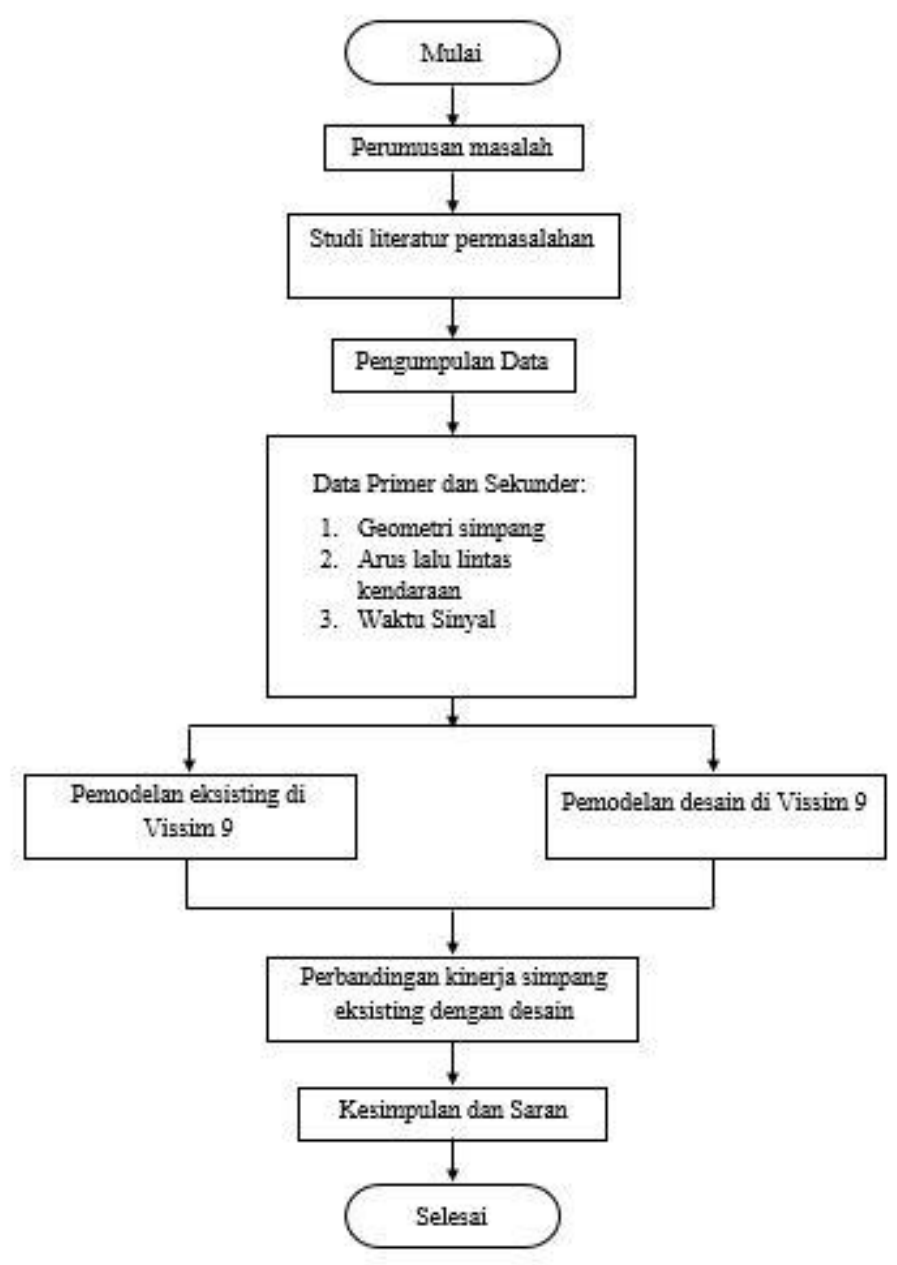

Gambar 1. Bagan alir

\subsection{Prosedur Pemodelan Simpang Pada Software PTV Vissim 9}

Berikut ini tahapan pemodelan simulasi lalu lintas menggunakan software PTV Vissim 9 (PTV, 2014):

1. Network Settings

Langkah pertama untuk pemodelan lalu lintas menggunakan software PTV Vissim 9 yaitu menyesuaikan parameter - parameter sesuai yang digunakan di Indonesia. Contohnya menyesuaikan satuan yang digunakan dan regulasi lalu lintas sebelah kiri.

2. Menentukan Jenis Kendaraan

Memasukan jenis kendaraan yang menyerupai dengan kendaraan di lapangan.

3. Kecepatan Kendaraan

Input data kecepatan kendaraan yang direncanakan yang akan dimodelkan dengan menggunakan desired speed decision.

4. Pembuatan Link

Pembuatan link jaringan jalan disesuaikan dengan data geometri jalan sehingga terbentuknya jaringan jalan yang menyerupai keadaan di lapangan.

5. Penentuan Rute Kendaraan dan Jumlah Kendaraan

Penentuan rute kendaraan dan jumlah kendaraan dilakukan sesuai dengan data arus lalu lintas kendaraan di lapangan pada masing-masing ruas jalan. Penentuan rute kendaraan dengan 
menggunakan static vehicle routes. Sementara untuk jumlah kendaraan pada ruas jalan dengan menggunakan vehicle input pada link.

6. Kalibrasi Model

Kalibrasi pemodelan yang dilakukan adalah mengubah nilai parameter perilaku berkendara, hal ini dilakukan dengan cara trial and error.

7. Validasi Model

Validasi dilakukan untuk menguji kebenaran hasil kalibrasi yang telah diterapkan pada pemodelan. Proses validasi yang dilakukan berdasarkan jumlah volume lalu lintas, perbandingan antara hasil keluaran volume lalu lintas pemodelan dengan volume lalu lintas survei menggunakan metode GEH (Geoffrey E. Havers) [6].

8. Perhitungan Jumlah Antrian dan Tundaan Kendaraan

Langkah selanjutnya yaitu menghitung jumlah antrian dan tundaan kendaraan sehingga dapat melakukan perbandingan eksisting dengan desain menggunakan node results.

\section{ANALISIS DAN PEMBAHASAN}

\subsection{Geometri Simpang}

Data geometrik persimpangan jalan PH.H.Mustafa dengan Jalan Cimuncang didapat dengan mengukur langsung masing - masing lebar pendekat menggunakan roda pengukur, dapat dilihat pada Gambar 2 dan Tabel 1.

Tabel 1. Data arus lalu lintas

\begin{tabular}{lcc}
\hline \multicolumn{1}{c}{ Nama Ruas Jalan } & $\begin{array}{c}\text { Lebar } \\
\text { Lajur } \\
\text { [meter] }\end{array}$ & $\begin{array}{c}\text { Tipe } \\
\text { Jalan }\end{array}$ \\
\hline $\begin{array}{l}\text { PH.H.Mustafa } \\
\text { (Cicaheum) }\end{array}$ & 3 & $4 / 2$ UD \\
\hline PH.H.Mustafa (Itenas) & 3 & $4 / 2$ UD \\
\hline Cimuncang & 3 & $2 / 2$ UD \\
\hline Ters.Cimuncang & 2,5 & $2 / 2$ UD \\
\hline
\end{tabular}

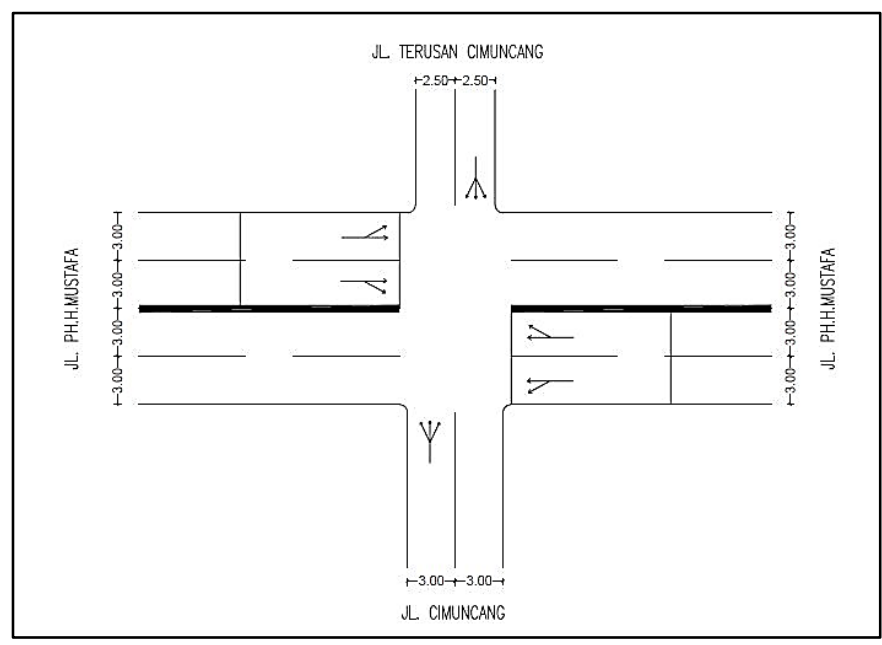

Gambar 2. Geometri persimpangan 


\subsection{Data Fase dan Lampu Sinyal Lalu Lintas}

Data fase dan lampu sinyal diperoleh dengan cara pengamatan langsung di lapangan menggunakan stopwatch dapat dilihat pada Gambar 3.

Fase I J1.PH.H.Mustafa

(Cicaheum)

Fase II J1.PH.H.Mustafa (Itenas)

Fase III Jl.Cimuncang \&

Ters.Cimuncang

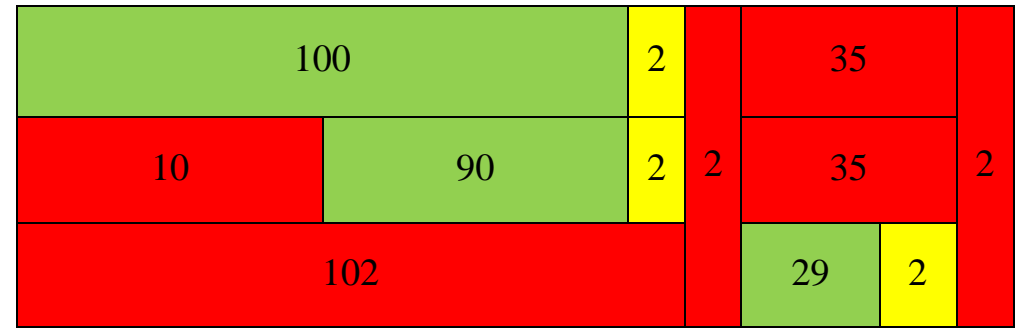

Gambar 3. Fase dan waktu sinyal

\section{Data Volume Lalu Lintas dan Persentase Pergerakan}

Data volume lalu lintas didapat dari pengamatan langsung dilapangan sedangkan data persentase pergerakan kendaraan diperoleh dari hasil penelitian sebelumnya, dapat dilihat pada Tabel 2 dan Tabel 3.

Tabel 2. Data arus lalu lintas

\begin{tabular}{|c|c|c|c|}
\hline \multicolumn{4}{|c|}{ Lengan Timur } \\
\hline Motor & Mobil & $\mathrm{HGV}$ & Total \\
\hline [kend/jam] & [kend/jam] & [kend/jam] & [kend/jam] \\
\hline 2901 & 891 & 74 & 3866 \\
\hline \multicolumn{4}{|c|}{ Lengan Barat } \\
\hline Motor & Mobil & $\mathrm{HGV}$ & Total \\
\hline [kend/jam] & [kend/jam] & [kend/jam] & [kend/jam] \\
\hline 2942 & 770 & 75 & 3787 \\
\hline \multicolumn{4}{|c|}{ lengan Selatan } \\
\hline Motor & Mobil & $\mathrm{HGV}$ & Total \\
\hline [kend/jam] & [kend/jam] & [kend/jam] & [kend/jam] \\
\hline 686 & 132 & 9 & 827 \\
\hline \multicolumn{4}{|c|}{ Lengan Utara } \\
\hline Motor & Mobil & $\mathrm{HGV}$ & Total \\
\hline [kend/jam] & [kend/jam] & [kend/jam] & [kend/jam] \\
\hline 573 & 66 & 12 & 651 \\
\hline
\end{tabular}

Tabel 3. Data pergerakan kendaraan di simpang

\begin{tabular}{ccccccc}
\hline \multicolumn{7}{c}{ Lengan Barat } \\
Pergerakan & $\begin{array}{c}\text { Motor } \\
{[\mathrm{kend} / \text { jam }]}\end{array}$ & $\begin{array}{c}\text { Mobil } \\
{[\mathrm{kend} / \text { jam }]}\end{array}$ & $\begin{array}{c}\mathrm{HGV} \\
{[\mathrm{kend} / \mathrm{jam}]}\end{array}$ & Total & $\begin{array}{c}\text { Total } \\
\text { Pergerakan }\end{array}$ & $\begin{array}{c}\text { Persentase } \\
{[\%]}\end{array}$ \\
\hline LT & 175 & 47 & 0 & 222 & 4460 & $5 \%$ \\
\hline ST & 2985 & 804 & 4 & 3793 & 4460 & $85 \%$ \\
\hline RT & 351 & 94 & 0 & 445 & 4460 & $10 \%$ \\
\hline Pergerakan & $\begin{array}{c}\text { Motor } \\
{[\mathrm{kend} / \text { jam }]}\end{array}$ & $\begin{array}{c}\text { Mobil } \\
{[\mathrm{k} \text { Lend/jam }]}\end{array}$ & $\begin{array}{c}\text { HGV } \\
{[\mathrm{kend} / \text { jam }]}\end{array}$ & Total & $\begin{array}{c}\text { Total } \\
\text { Pergerakan }\end{array}$ & Persentase \\
\hline LT & 13 & 3 & 1 & 17 & 312 & $6 \%$ \\
\hline
\end{tabular}




\begin{tabular}{ccccccc} 
ST & 220 & 43 & 1 & 264 & 312 & $84 \%$ \\
\hline RT & 26 & 5 & 0 & 31 & 312 & $10 \%$ \\
\hline Pergerakan & $\begin{array}{c}\text { Motor } \\
{[\mathrm{kend} / \text { jam }]}\end{array}$ & $\begin{array}{c}\text { Mobil } \\
{[\mathrm{kend} / \text { jam }]}\end{array}$ & $\begin{array}{c}\text { HGV } \\
{[\mathrm{kend} / \mathrm{jam}]}\end{array}$ & Total & $\begin{array}{c}\text { Total } \\
\text { Pergerakan }\end{array}$ & $\begin{array}{c}\text { Persentase } \\
{[\%]}\end{array}$ \\
\hline LT & 162 & 43 & 1 & 204 & 4103 & $5 \%$ \\
\hline ST & 2752 & 728 & 7 & 3487 & 4103 & $85 \%$ \\
\hline RT & 324 & 86 & 0 & 410 & 4103 & $10 \%$ \\
\hline Pergerakan & Motor & Mobil & HGV & Total & Total & Persentase \\
\hline LT & 40 & 5 & 0 & 45 & 4103 & $5 \%$ \\
\hline ST & 684 & 78 & 2 & 764 & 4103 & $85 \%$ \\
\hline RT & 81 & 10 & 0 & 91 & 4103 & $10 \%$ \\
\hline
\end{tabular}

\subsection{Data Kecepatan Kendaraan}

Data kecepatan diperoleh dari penelitian sebelumnya yang berupa rekaman pengamatan ruas jalan selama 1 jam, selanjutnya dilakukan pengolahan data dengan mengamati hasil rekaman survei. Pengolahan data dilakukan dengan cara mengukur jarak marka jalan yang telah ditentukan dan waktu tempuh masing - masing kendaraan untuk melewati marka jalan yang sudah ditentukan, sehingga didapatlah kecepatan dari kendaraan tersebut. Gambar 4, 5 dan 6 berikut ini adalah hasil pengolahan data kecepatan.

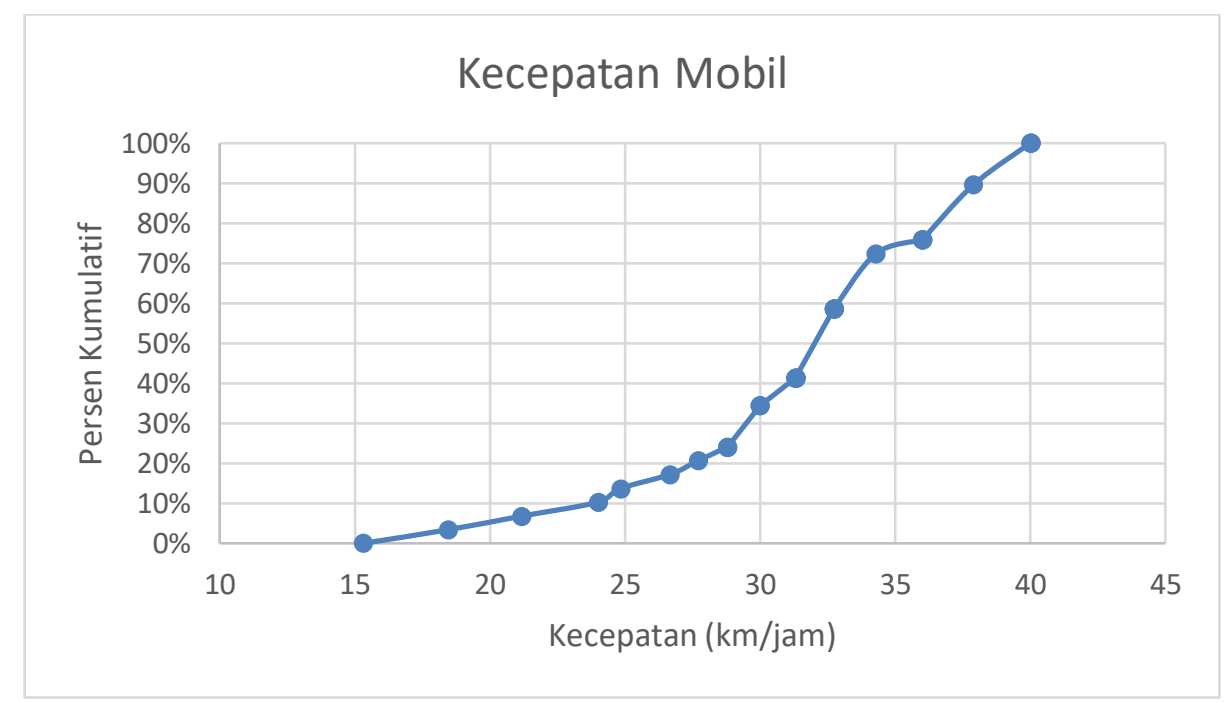

Gambar 4. Grafik distribusi kecepatan mobil 


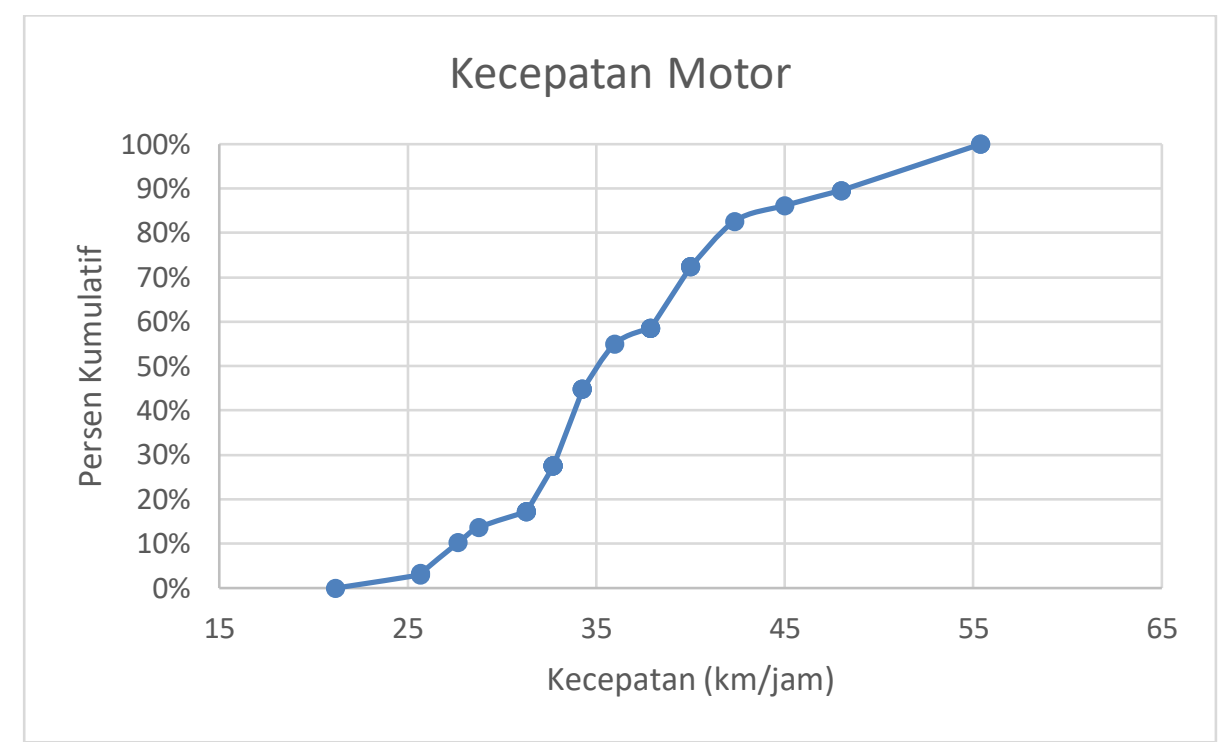

Gambar 5. Grafik distribusi kecepatan motor

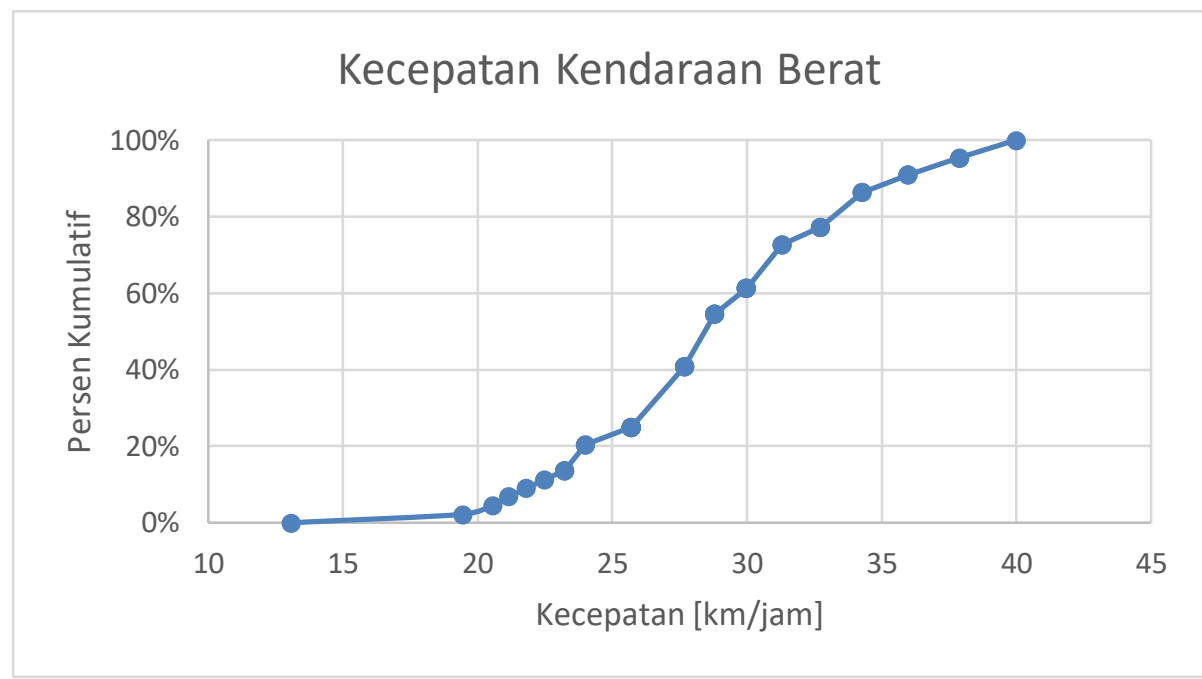

Gambar 6. Grafik distribusi kecepatan kendaraan berat

\subsection{Analisis Pemodelan Simpang Eksisting}

Setelah data - data yang dibutuhkan dalam memodelkan didapatkan dan diolah. Berikutnya adalah memodelkan dan menganalisis persimpang Jl.PH.H.Mustafa - Jl.Cimuncang eksisting menggunakan software Vissim 9. Proses kalibrasi dilakukan terhadap geometri simpang dan perilaku pengemudi. Parameter kalibrasi perilaku pengemudi yang digunakan pada penelitian ini menggunakan parameter wideman 74 yang diadopsi dari penelitian sebelumnya yang berjudul "Mikrosimulasi Mixed Traffic Pada Simpang Bersinyal Dengan Perangkat Lunak Vissim” [2]. Parameter kalibrasi tipe Wideman 74 yang digunakan pada penelitian ini dapat dilihat pada Tabel 4. 
Tabel 4. Parameter kalibrasi

\begin{tabular}{llcc}
\hline \multirow{2}{*}{ No. } & & Parameter yang diubah & \multicolumn{2}{c}{ Nilai } \\
\cline { 3 - 4 } & & Default & (Putri, 2015) \\
\hline 1 & Desired position at free flow & middle of & any \\
\hline 2 & Overtake on same lane: on left \& on right & off & on \\
\hline 3 & Minimum Distance Standing at $0 \mathrm{~km} / \mathrm{h}$ & 1 & 0,2 \\
\hline 4 & Minimum Distance driving at $50 \mathrm{~km} / \mathrm{h}$ & 1 & 0,4 \\
\hline 5 & Average standing at $0 \mathrm{~km} / \mathrm{h}$ & 2 & 0,6 \\
\hline 6 & Additive part pf safety distance & 2 & 0,6 \\
\hline 7 & Multiplicative part of safety distance & 3 & 1 \\
\hline
\end{tabular}

\subsection{Validasi}

Validasi merupakan pengujian yang dilakukan setelah kalibrasi selesai. Validasi adalah suatu ukuran yang menunjukan tingkat kevalidan suatu pemodelan. Proses validasi melibatkan perbandingan hasil simulasi dengan data observasi. Dalam studi ini, arus lalu lintas digunakan sebagai pembanding antara hasil pemodelan dengan hasil observasi. Untuk membandingkan data input dan output simulasi adalah dengan menggunakan rumus statistik GEH (Geoffrey E. Havers). Rumus GEH berikut ini memiliki ketentuan khusus dari nilai error yang dihasilkan seperti pada Tabel 5.

halmana:

$$
\mathrm{GEH}=\sqrt{\frac{\left(\mathrm{q}_{\text {pemodelan }}-\mathrm{q}_{\text {observasi }}\right)^{2}}{0.5 \times\left(\mathrm{q}_{\text {pemodelan }}+\mathrm{q}_{\text {observasi }}\right)}}
$$

$\mathrm{q}=$ data arus lalu lintas $[\mathrm{kend} / \mathrm{jam}]$.

$\mathrm{q}_{\mathrm{pemodelan}} \quad=$ data arus lalu lintas hasil pemodelan[kend/jam].

qobservasi = data arus lalu lintas hasil observasi[kend/jam].

Tabel 5. Standar Perhitungan Persamaan GEH

\begin{tabular}{cc}
\hline Nilai GEH & Keterangan \\
\hline$<5,0$ & Diterima \\
\hline $5,0 \leq \mathrm{GEH} \leq 10,0$ & Peringatan: kemungkinan model error atau data buruk \\
\hline $\mathrm{GEH}>10$ & Ditolak \\
\hline
\end{tabular}

Validasi kondisi arus lalu lintas observasi dan pemodelan divalidasi dengan menggunakan metode Geoffrey E. Havers (GEH) [6], didapatkan nilai rata - rata $\mathrm{GEH}<5$ per lengan simpang. Hasil validasi disampaikan pada Tabel 6. 
Tabel 6. Hasil Validasi

\begin{tabular}{lccc}
\hline \multirow{2}{*}{$\begin{array}{c}\text { Lengan } \\
\text { Simpang }\end{array}$} & \multicolumn{2}{c}{ Volume Lalu Lintas [kend/jam] } & \multirow{2}{*}{ Uji GEH } \\
\cline { 2 - 3 } & Hasil Survei & Hasil Pemodelan & \\
\hline Timur & 3866 & 3926 & 0,961 \\
\hline Barat & 3787 & 3751 & 0,586 \\
\hline Selatan & 827 & 779 & 1,694 \\
\hline Utara & 651 & 659 & 0,313 \\
\hline \multicolumn{3}{c}{ Rata - rata uji GEH } & 0,889 \\
\hline
\end{tabular}

Pemodelan simpang eksisting sudah memenuhi persyaratan uji GEH dengan cara membandingkan arus lalu lintas pemodelan dengan arus lalu lintas observasi atau survei, sehingga dapat dikatakan pemodelan yang dilakukan sudah menyerupai keadaan lalu lintas yang terjadi dilapangan.

\subsection{Hasil Evaluasi Simpang Eksisting}

Hasil keluaran kinerja simpang dari pemodelan hanya meninjau panjang antrian dan tundaan. Berikut adalah hasil panjang antrian dan tundaan dari pemodelan Tabel 7.

Tabel 7. Hasil evaluasi pemodelan eksisting

\begin{tabular}{lcc}
\hline Lengan Simpang & Antrian [meter] & Tundaan [detik] \\
\hline Timur & 15,66 & 16,68 \\
\hline Barat & 21,46 & 26,13 \\
\hline Selatan & 70,94 & 201,76 \\
\hline Utara & 28,72 & 83,24 \\
\hline
\end{tabular}

\subsection{Skenario Pemodelan Desain}

Berdasarkan Skenario pemodelan dilakukan dengan menambah lebar geometri jalan selebar 2,5m untuk lajur khusus sepeda motor di jalan PH.H.Mustafa arah Cicaheum dan Itenas. Pembatas lajurnya menggunakan marka jalan dapat dilihat pada Gambar 7.

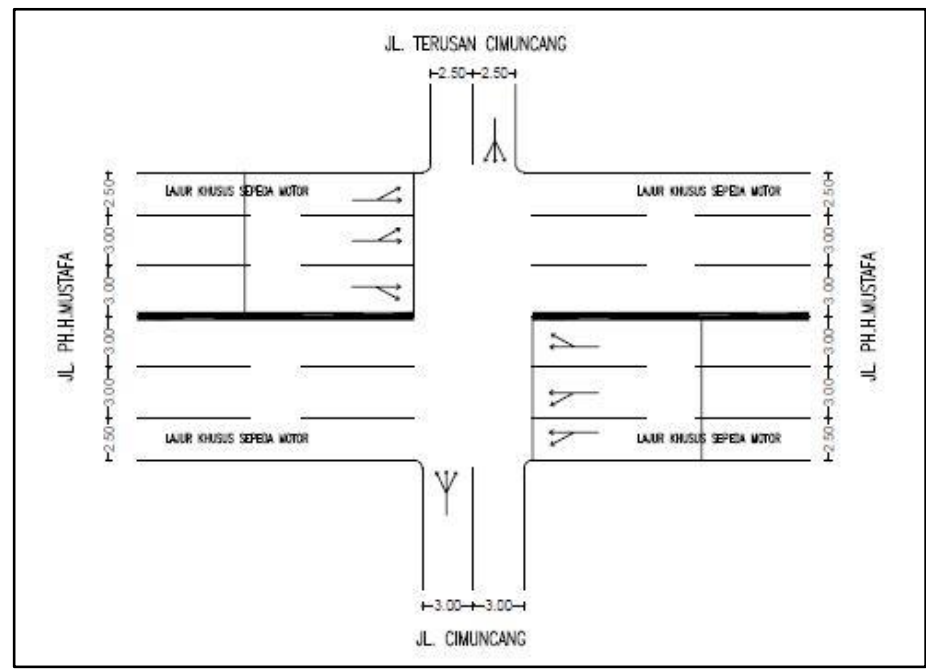

Gambar 7. Skenario pemodelan desain

Jurnal Rekayasa Hijau - 125 


\subsection{Hasil Evaluasi Skenario Pemodelan Desain}

Skenario pemodelan desain dilakukan dengan tahap - tahapan yang sama seperti dilakukan pada saat pemodelan eksisting. Perbedaannya adalah ada penambahan lebar geometri di lengan timur dan barat sebesar 2,5m, juga ada perbedaan masukan volume lalu lintas beserta komposisi pergerakan kendaraan di lajur utama PH.H.Mustafa akibat terfokusnya pergerakan sepeda motor di lajur khusus yang telah disediakan. Hasil keluaran kinerja simpang yang ditinjau sama seperti pemodelan eksisting yaitu panjang antrian dan tundaan. Berikut ini adalah hasil panjang antrian dan tundaan dari skenario pemodelan desain Tabel 8.

Tabel 8. Hasil evaluasi pemodelan desain

\begin{tabular}{lcc}
\hline \multicolumn{1}{c}{ Lengan Simpang } & Antrian [meter] & Tundaan [detik] \\
\hline Timur & 6,18 & 11,14 \\
\hline Barat & 12,6 & 18,55 \\
\hline Selatan & 66,77 & 177,39 \\
\hline Utara & 23,03 & 65,34 \\
\hline
\end{tabular}

\subsection{Perbandingan Hasil Kinerja Simpang Eksisting dengan Desain}

Hasil keluaran kinerja simpang khususnya panjang antrian dan tundaan dari pemodelan eksisting dengan desain dibandingkan perubahannya. Berikut adalah perbandingan dari kedua hasil pemodelan Tabel 9.

Tabel 9. Hasil evaluasi pemodelan eksisting

\begin{tabular}{|c|c|c|c|c|c|c|}
\hline \multirow{2}{*}{ Lengan Simpang } & \multicolumn{2}{|c|}{ Antrian [meter] } & \multirow{2}{*}{ Persen Selisih [\%] } & \multicolumn{2}{|c|}{ Tundaan [detik] } & \multirow{2}{*}{$\begin{array}{c}\text { Persen } \\
\text { Selisih } \\
{[\%]}\end{array}$} \\
\hline & Eksisting & Desain & & Eksisting & Desain & \\
\hline Timur & 15,66 & 6,18 & 60,54 & 14,62 & 11,14 & 23,80 \\
\hline Barat & 21,46 & 12,6 & 41,29 & 26,13 & 18,55 & 29,01 \\
\hline Selatan & 70,94 & 66,77 & 5,88 & 201,76 & 177,39 & 12,08 \\
\hline Utara & 28,72 & 23,03 & 19,81 & 83,24 & 65,34 & 21,50 \\
\hline
\end{tabular}

\subsection{Kesimpulan}

\section{KESIMPULAN DAN SARAN}

Berdasarkan analisis yang telah dilakukan menggunakan software PTV Vissim 9, dapat disimpulkan beberapa hal sebagai berikut:

1. Hasil pemodelan analisis kinerja simpang yang ditinjau adalah panjang antrian dan tundaan. Penjelasan hasil pemodelan simpang eksisting menunjukan bahwa pada jalan PH.H. Mustafa arah Cicaheum terdapat antrian 15,66 m dan tundaan 14,62 detik sedangkan arah Itenas antrian sebesar 21,46 m dengan tundaan 26,13 detik. Pada jalan Cimuncang terdapat antrian 70,94 m dan tundaan 201,76 detik sedangkan di jalan terusan cimuncang terdapat antrian $28,72 \mathrm{~m}$ dengan tundaan 83,24 detik.

2. Hasil analisis kinerja simpang setelah adanya lajur khusus sepeda motor, terjadi penurunan panjang antrian dan tundaan. Penurunan panjang antrian di jalan PH.H.Mustafa arah Cicaheum 
dan Itenas berkisar $8 \mathrm{~m}$ sampai $9 \mathrm{~m}$ dengan tundaan berkisar 3 detik sampai 7 detik. Penurunan panjang antrian di jalan Cimuncang berkisar 4m sampai 5m dengan tundaan berkisar 17 detik sampai 24 detik.

\subsection{Saran}

Saran yang dapat diberikan untuk selanjutnya berkaitan dengan analisis pengaruh lajur khusus sepeda motor terhadap kinerja simpang adalah melakukan survei panjang antrian dilapangan, sehingga validasi tidak hanya terhadap volume lalu lintas namun juga bisa terhadap panjang antrian.

\section{DAFTAR RUJUKAN}

[1] Zukhruf F., Frazila R.B., Wibowo S.S. 2010. Efektivitas Jalur Sepeda Motor Pada Jalan Perkotaan Menggunakan Model Simulasi-Mikro.

[2] Putri, N. H., \& Irawan, M. Z., 2015. Mikrosimulasi Mixed Traffic pada Simpang Bersinyal dengan Perangkat Lunak Vissim (Studi Kasus: Simpang Tugu, Yogyakarta). Yogyakarta: Universitas Gadjah Mada.

[3] Algifar . 2017. Analisis Mikro-Simulasi Lalu Lintas Pada Rencana Pengoperasian Underpass Di Simpang Mandai Makasar.

[4] Maulana, A., 2017. Pengaruh Kebijakan "““4 in 1"” Terhadap Kinerja Persimpangan J1 Dr. Djunjunan-Tol Pasteur dengan Menggunakan Simulasi Mikro. Jurnal Rekayasa Hijau, 1(1).

[5] Buchari, E dan Saputra, M.R. 2011. Travel Behaviour of Motorcyclist in Congestion and Limited Infrastructure Condition.

[6] PTV VISION. 2014. PTV VISSIM 7 User Manual. PTV AG. Karlsruhe. Germany. 
